\title{
A Challenge of Macro-Meso-Micro Analysis Impacts on Multiracial Nationality Decision Making: Multiracial Thai-Japanese in Bangkok
}

\author{
Thanapum Limsiritong1, Tomoyuki Furutani ${ }^{2}$, Karnjira Limsiritong ${ }^{3}$ \\ 1,2 Graduate School of Media and Governance, Keio University, Japan \\ ${ }^{3}$ Doctoral program of Business Administration's, Siam University, Thailand
}

\begin{abstract}
Nationality decision-making immensely impacted to country structural, society issues, and future population which factors could dramatical advantages to Thailand-Japan or other countries toward the possibility of multiracial nationality decision making, policy approach to future population and international labor management. This research purposed (1) To study the possibility factors of multiracial decision making (2) To adjust the factors impact on multiracial decision making into a model prediction (3) To assess a model in the separation of developing and developed country context toward multiracial decision making. There were 685 dual ThaiJapanese under-sampling criteria, and a questionnaire survey was conducted by purposive sampling online at Bangkok as the biggest majority province of Japanese migrants in Thailand. PLS-SEM was considered to assess a formative measurement from lower to higher-order and mediation model of macro, meso, and micro levels by using SMART-PLS 3.0. The results indicated that Thailand's macro-level should concern about "Political and governance", and "Hospital and wellness". Japan macro level should consider to "Economic", and "Working environment". Moreover, Thailand's meso level had more issues on development factors than Japan, afterward meso factor as an individual background and experience reports that education and passport competency support to multiracial nationality decision making to both Thailand and Japan. As a result, Thailand's macro, meso, and microstructure presented the irrelevance between macro, meso, and micro, which caused to un-support of nationality decision making meanwhile Japan had the potential to escalate a policy toward significant both direct and indirect to multiracial nationality decision making.
\end{abstract}

Keywords: Multiracial, Thailand, Japan, Nationality Decision Making, PLS-SEM Model

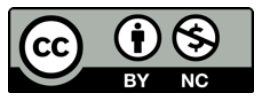

This is an open access article under the CC-BY-NC license.

\section{INTRODUCTION}

Multiracial among the crucial globalization situation according to the statement of 2010 U.S. Census announced to over 9 million people (2.9\% of the total world population) identify with more than one race, having grown $32 \%$ since 2000 and expected to increase $180 \%$ by 2050 (Vespa. J, et al., 2020). This number was predicted to be the number of identified multiracial people. Definitely, this situation will affect the transformation of the international society from a homogenous community to an international network. As an example, for the changing in "Bill of Rights in 2000" on Census form (Perlman, 2002) which expanded the definition from choosing one's race-ethnicity to not be defined by others based on appearance or a predefined racial categorization system.

Since this significant shift in identity politics, increasing numbers of individuals born to interracial unions are more likely to claim a mixed-racial-ethnic heritage in the social atmosphere of increased acceptance. It means the governance approach could affect social perception and give the direction of society attitude to international transformation as well. While there is a lot of conflict situations of racism, social discrimination, and acceptance, the multiracial group is still under the way of studying, according to the lack of a very few on data access and none of each government data report officially. Thailand-Japan and many countries are still under the way of protocol and practical management; nationality law seems to be the only concrete evidence to due in this situation which might cause nationality issues of misunderstanding. 
This research concerned multiracial decision making especially in the case study of Thailand -Japan, because of the highest FDI investment to Thailand over 10 years(BOI,2010-2019). These investment projects have become a situation of multiracial Thai-Japanese in both Japan and Thailand over a decade.

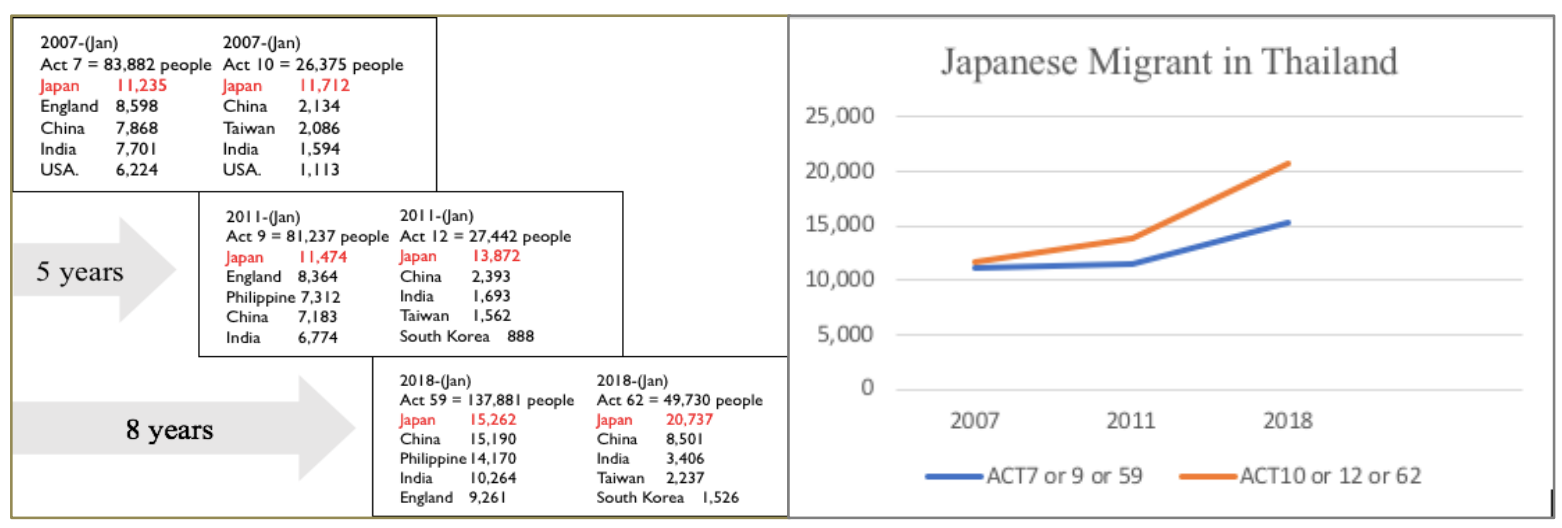

Figure 1. Japanese migrant in Thailand source Japan embassy in Thailand

The number of Japanese migrant statistics from ACT7 or 9 or 59 could possibly multiply over the number of ACT10 or 12 or 62 according to Japan economy strategy, which means the unknown and unclear number of dual racial or multiracial could possibly become a big crucial issue between two countries by against the nationality law of Japan and matter conditional in Thailand as well. As a result, this situation needs to be addressed as a possibility factor in the level of macro, meso, and micro situation to a country status that relates to nationality decision making.

\section{Word definitions in this research}

1. Migrant a person who moves from origin country to destination country in order to seek a better life such as migrant workers (low skilled and skilled labor)

2. One racial person who choose one nationality

3. Multiracial a person who have 2 and more nationalities relative to their original races, ethnics

4. Multiracial decision making a person who decides to be one race or keep both or more nationalities

\section{$\underline{\text { Research objectives }}$}

1. To study the possibility factors of multiracial decision-making.

2. To adjust the factors' impact on multiracial decision-making into a model prediction.

3. To assess a model in the separation of developing and developed country context toward multiracial decision making.

\section{LITERATURE REVIEW}

\section{Push and Pull issues adapt to the multiracial situation}

The push and Pull concept have been used in many fields of study. The main reason was to find the negative and positive points which could interpret to Push and Pull indicators or situations. In terms of tourism and migration had a characteristic of being abroad as similar as multiracial groups in some points, but there were differences in push or pull, timing, a given rights that authorized by the state, or and purposes. Accordingly, tourism developments from not only policy strategies but also local activities could be an important influence of positive and negative which affected to decision making of travelers and the trend of shorter and longer staying in long-term tourism sustainable management (Siripen \& Wongleedee, 2014). To be clearer, tourism push factors could be a 'self-motivation (decision making)' meanwhile pull 
factors came from perception toward destination, experiences, time and cost of money expense that all motivated to push factors by the original environment, relaxation purpose, personal reasons and also pull factors by satisfaction elements of tourist (Said, J. \& Maryono, M., 2017).

Migration contexts have broadened this conceptual idea to evaluate risk management and possibilities to impact both origin and destination issues and decision making. Owing to the characteristic of migrants differentiated from tourist such as long-term staying period across generation to next-generation which means the group of migrants tended to impact more on both origin and destination countries structure in longer time.

Considering the indicators of the United Nations Migration report 2016 evaluation. It compared between Thailand and Japan through human development, human security, safety and security protocol, domestic society environment dimensions, focusing on the status measurement by UN it

proved that policy on migration could represent the need of international migrants into 3 statuses of Raise / Maintain/ and Lower. This measurement related to the policy of highly skilled of raising up in the different context of a developed and developing country which means push and pull factors on migrant were impacted in a longer-term period of FDI investments and economic concerns possibly.

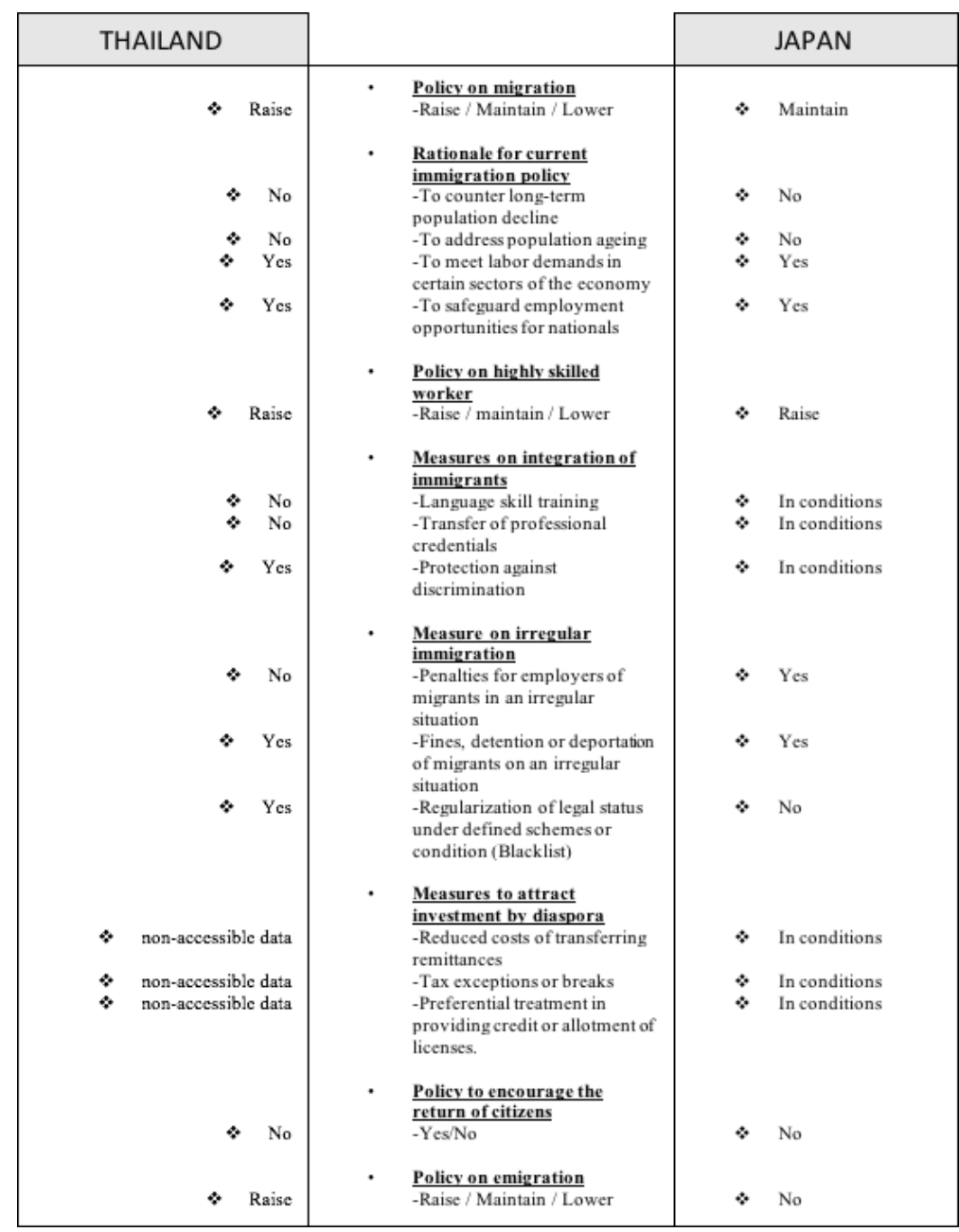

Figure 2. UN migration indicators to Thailand and Japan in comparing source UN migration report 2016

As similar as a skilled professional worker had more influences in terms of countries development sectors (ex. IT and Electronic components) in a positive impact such as in Europe indicated the increase of services industry GDP accumulated up to 9.4 percent from 1980 to 1994, as similar as in the Americas was increased up to 6.4 percent in the same period of time as Europe (Bhorat, H., Meyer, J. \& Mlatsheni, 2002). According to the push issues caused by individual migrant reasons such as language barrier and 
cultural differences adaptation toward destination society concerned to some conflict situations (Anwar, R., 2019).

Consequently, low-skilled labor and skilled labor had a different problem, mostly low-skilled labor has been addressed to a negative impact to clarify their legal rights and labor legislation in terms of destination countries context that could possibly cause by human trafficking or social discrimination so that legalized process would help workers to relate their aliened status with stakeholders and country organizations positively (Gursharan, 2010).

However, there was not only a difference between tourist and migrant characteristics but also push and pull toward country structure elements. The multiracial group could represent both groups in terms of being given rights authorities naturally from the origin and destination government policies which has been tended to force the decision making in racial identification individually for the conditions and against the protocol possibly. Previously, there were some studies that indicated that family and community factors could reference self-identification (LaBarries, 2017) but mostly focused on community and or local situation factors and or psychological decisions as same as racial identification (Radina \& Cooney, 2000). In the real situation, the interesting point of multiracial contexts indicated that why they wanted to keep dual nationality without information to the state if it has been against the law and policies?

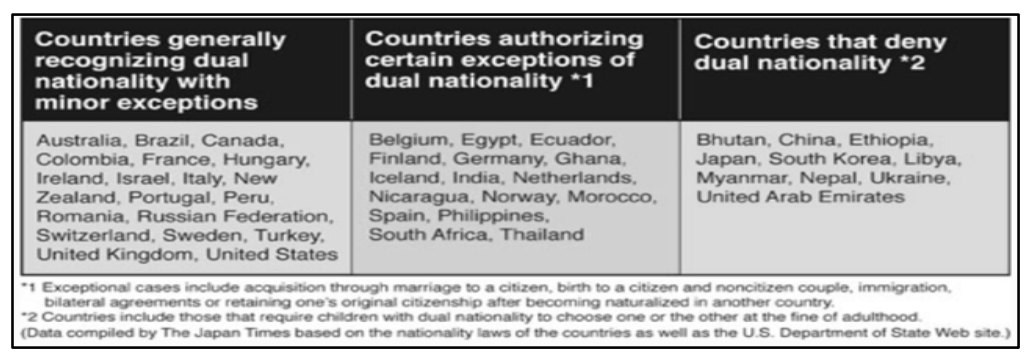

Figure 3. Dual nationality permission country, Harriet Cann (MAP: Dual citizenship around the world)

In this research, the Push and Pull factor from the migration factor would be adapted to study in terms of indicators to fulfill the possibility of multiracial decision making among the lack of studying of push and pull factors in the context of a developed and developing country.

\section{Macro, Meso, and Micro-structure development impact of migrant towards multiracial identification}

To move forward in searching for better living conditions more than his or her origin country has become a big phenomenon of international migrant which could happen over generations.

Macro, meso, and micro were addressed as the structure where included a variety of elements (push and pull) of country developments. Especially, economic compassing, environmental, social, and political factors drove a person out to the attractive destination country (LEE, A., 1996).

Passing through this analysis would estimate the potential and statement problem to overcome with the development policy goals. For instance, Thailand has been trying to escalate from an upper-middleincome to a high-income economy by 2037. In order to do so, macro meso and microstructure in the future policy strategy would perform in creating strong cities in regions, achieving better financing for local government, and moving from crisis to risk management in the local situation (OECD, 2019). Moreover, this strategy analysis could play a significant role in pointing out the possible problem of future development as well. To illustrate, Japan had two significant challenges on a record high government debt ratio, and the decline in the working-age population, the concept of economic driving Japan or Three arrows of Abenomics used to be a Japan strategy in overcoming the situation by population restructured and imported international labor in order to support a micro sector (OECD,2017). 
For migrant decision making, by using macro, meso, and micro factors were situated together to an output of decision to migrate, it would indicate to both origin and destination country situations and type of migrant. In this sense, decision-making could construct in comparison in each layer, but it had to be completely looked into every layer performing and acting together. To consider what should be in macro-, meso-, and micro- of immigration analysis showed that macro-structure related to political, socioeconomic, environmental situations. Meso- structure related to the link between macro-and microstructure such as media, communication technology, and or some issues that raise the awareness of living quality. Microstructure related to individual information such as age, gender, education, status, religion, language (Castelli, F., 2018).

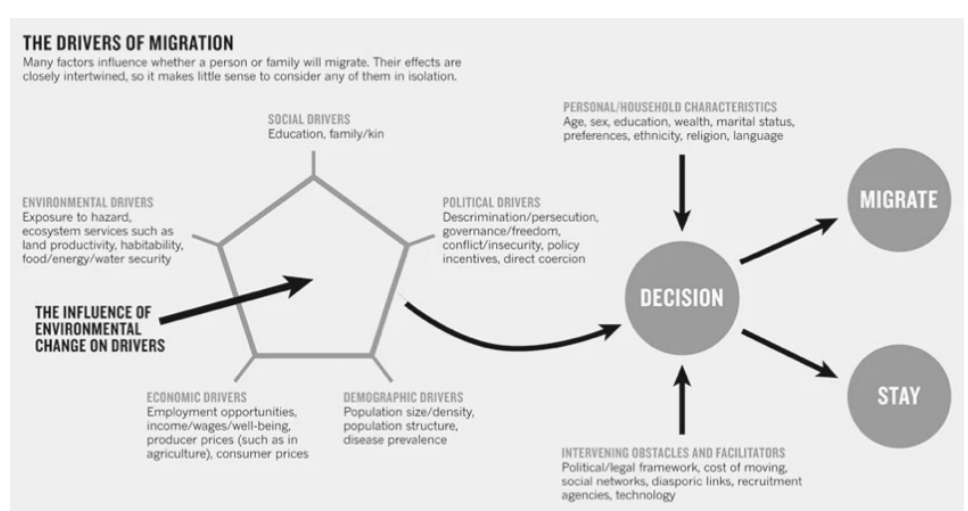

Figure 4. Framework model of the drivers of migration

Source Foresight: Migration and Global Environmental Change Final Project Report (Government Office for Science 2011)

There was a study of ethnic/racial minority adolescents in the USA indicated that social status and identities of ethnic identity and American identity impacted the same on school engagement activity with racism and discrimination (Cheon, Y., Ip, P., Haskin, M. \& Yip, T., 2020). This study showed that social structure and social justification could affect decision-making in forming the identity, which could account for the structure of developments that shaped the awareness differently between local and multiracial status.

Furthermore, the crucial situation of multiracial issues could be a very crucial of country structure in positive and negative for example, over $52 \%$ of US citizen "immigrants or other race today strengthen our country because of their hard work and talents," meanwhile $45 \%$ said, "immigrants and other race today are a burden on our country because they take our jobs, housing, and health care." (Parker, K., 2015)

To be specific, racial identification has been focusing on a narrow point of the situation and mostly conducted the research in qualitative method which could not reflect the possibility of development structure impact, adaptation the theory of macro, meso, and micro-structure might be a solution to a better understand the situation of multiracial through factors under the development structural in alternative consideration procedure.

For multiracial situations, the real decision making provided into two choices; one race of Thai or Japanese and or dual nationality without being informed to the government legislation. To adapt a keys driver of the migrant to the multiracial group would be an exploratory experiment to understand this decision in reference from both origin and destination country crucially.

\section{RESEARCH METHODOLOGY}

The quantitative method was used to collect the data online $(\mathbf{n}=\mathbf{6 8 5})$ in cooperating with Japanese associations in Thailand groups, Japanese society online groups, Multiracial Thai-Japanese society online groups, Long-stay agencies, and Japan Embassy in Thailand from November 2019 to March 2020.

There was no data of Thai-Japanese multi-nationality or international marriage by Thailand government official statistic report officially. According to the increasing number in every year of Japanese long-stay registration accounted to 73,000 people from Japan embassy in Thailand (2019), the biggest majority group of Japanese long-stay lived in Bangkok for 53,000 people who accumulated to $72.6 \% » 73 \%$ compared from the total. The infinite population was used to consider in the sampling size, (Cochran, 1953) sampling size with estimation to the population proportion formulated to $95 \%$ of confidential level with $\mathrm{e}=.05$ in result to $\mathrm{n}=449$ in a minimum of sampling size. 
Purposive sampling was used to collect sampling in specific conditions: (1) Thai-Japanese multiracial who are in the aged of 18 years old in minimum and over (2) Living in Thailand and having a resident place in Japan (3)Having Japanese mother/father or and relative in Thailand (4)Having or Used to have a moment experience to live in Japan for purposes such as working, visiting friend and relative, and studying. Besides, the item in the questionnaire for each item was in between .60-1.0, which passed the standard of .50 of IOC validity score from 5 specialists in the tourism and migration field. After that, the pilot questionnaire from the first try out of 60 respondents was collected to test the reliability of Cronbach alpha; the score passed the standard score $\alpha=.816$. Moreover, the questionnaire was comprised of 4 parts: (1) Demographic data, (2)Background of living in Thailand and Japan, (3) Thailand factors $(\alpha=.949: 26$ items in 7 Likert scales) as same as Japan factors $(\alpha=.952: 26$ items in 7 Likert scales), and (4)Returning (if)reasons. Furthermore, all the information of respondents was used only for this research purpose. Anonymity and security measures were used to promise to all respondents.

This research was considered in advance of using PLS-SEM to assemble the formative measurement model lower order to higher order and mediation in the testing of multiracial nationality decision making (one race and dual race) by using SMART PLS 3.0. bootstrapping algorithm for 5,000 samples with a 95\% confidential level. The algorithm generated the data four 4 times according to the different nationality decision-making of Thailand and Japan.

\section{FINDING AND DISCUSSION \\ Descriptive statistic report}

A female accounted for $58.8 \%$ more than a male. The status of the respondent was single $41.6 \%$ meanwhile $54.9 \%$ was in marital status. The level of education indicated the most multiracial ThaiJapanese having a higher education level to $83.8 \%$. Moreover, as a skilled worker and doing business of $73.7 \%$. The income range is higher than the standard of Thailand, from $30,000-200,000$ to $52.4 \%$. The group was able to communicate in trilingual Thai, English, and Japanese at $85.7 \%$ and $85.1 \%$, respectively. There was the highest of willing to stay in Thailand only for $74.6 \%$ meanwhile the other reasons might return to Japan by family decision, relationship, business, education, and health respectively.

Significantly, the statistic report presented the status, role, background, and language skills that could possibly address the characteristic of the Thai-Japanese group in Bangkok. While higher education supported the status of a good job capability and better salary wage, also language's ability might be able to represent as the tools of being able to live in both countries as well. Furthermore, the reasons to return to Japan seemed to be a personal reason more than seeking the advantages of living in Japan permanently.

\section{Lower order variable construction (Thailand and Japan)}

Formative measurement indicators had been constructed by weight and Tvalues, which considered to VIF not over 10, meaning to acceptable to use as a measurement factor ( $O$ 'brien. $R, 2007)$. Moreover, in the next step to construct a higher order, the factors were checked with outer weight and outer loading, respectively.

Political and governance, economic, working environment, society and culture, and hospital and wellness were represented to country structure and infrastructure developments. The elements of these issues were adapted to push and pull issues while these indicators indicated from the key drivers form of migration decision making as well. Importantly, adapting the key assessments in the context of nationality decision making in reference function between long-stay tourism and migration, this model could possibly evaluate the possibility of situations that could impact nationality decision making in this matter. 
Table 1. Thailand and Japan indicators validation

\begin{tabular}{|c|c|c|c|c|c|}
\hline Construct (Thailand indicators) & Item & Scale & Weights & Tvalues & VIF \\
\hline \multirow{4}{*}{ Political and Governance } & TP1 & Formative & 0.406 & 8.449 & 2.730 \\
\hline & TP2 & & 0.294 & 4.893 & 3.445 \\
\hline & TP3 & & 0.377 & 10.252 & 1.784 \\
\hline & TP4 & & 0.090 & 1.728 & 1.420 \\
\hline \multirow[t]{4}{*}{ Economic } & TE1 & Formative & 0.295 & 5.071 & 2.262 \\
\hline & TE2 & & 0.350 & 7.070 & 2.086 \\
\hline & TE3 & & 0.207 & 4.137 & 2.023 \\
\hline & TE4 & & 0.332 & 7.656 & 1.885 \\
\hline \multirow[t]{3}{*}{ Working environment } & TW1 & Formative & 0.667 & 18.401 & 1.594 \\
\hline & TW2 & & 0.494 & 7.537 & 1.801 \\
\hline & TW3 & & -0.042 & 0.618 & 1.776 \\
\hline \multirow[t]{4}{*}{ Society and Cultural } & TS1 & Formative & 0.638 & 13.218 & 1.712 \\
\hline & TS2 & & 0.132 & 2.417 & 1.574 \\
\hline & TS3 & & 0.004 & 0.099 & 1.074 \\
\hline & TS4 & & 0.533 & 11.862 & 1.226 \\
\hline \multirow[t]{3}{*}{ Hospital and Wellness } & TH1 & Formative & -0.625 & 9.771 & 1.045 \\
\hline & TH2 & & 0.334 & 5.271 & 1.268 \\
\hline & TH3 & & 0.563 & 9.292 & 1.242 \\
\hline Construct (Japan indicators) & Item & Scale & Weights & Tvalues & VIF \\
\hline \multirow[t]{4}{*}{ Political and Governance } & JP1 & Formative & 0.164 & 3.623 & 3.228 \\
\hline & JP2 & & 0.052 & 0.996 & 3.548 \\
\hline & JP3 & & 0.164 & 2.829 & 4.862 \\
\hline & JP4 & & 0.696 & 19.205 & 2.831 \\
\hline \multirow[t]{4}{*}{ Economic } & JE1 & Formative & 0.210 & 2.668 & 1.594 \\
\hline & JE2 & & 0.122 & 0.940 & 5.911 \\
\hline & JE3 & & 0.566 & 4.527 & 5.919 \\
\hline & JE4 & & 0.408 & 5.291 & 1.708 \\
\hline \multirow[t]{3}{*}{ Working environment } & JW1 & Formative & 0.455 & 7.606 & 1.046 \\
\hline & JW2 & & 0.058 & 0.775 & 1.410 \\
\hline & JW3 & & -0.809 & 8.179 & 1.363 \\
\hline \multirow[t]{4}{*}{ Society and Cultural } & JW1 & Formative & 0.382 & 8.003 & 2.149 \\
\hline & JW2 & & 0.319 & 9.667 & 1.915 \\
\hline & JW3 & & -0.456 & 8.945 & 1.546 \\
\hline & JW4 & & -0.116 & 3.410 & 1.370 \\
\hline \multirow[t]{3}{*}{ Hospital and Wellness } & JH1 & Formative & 0.704 & 4.865 & 5.917 \\
\hline & $\mathrm{JH} 2$ & & -0.060 & 0.379 & 5.708 \\
\hline & JH3 & & -0.529 & 13.186 & 1.233 \\
\hline
\end{tabular}

\section{Higher-order / Mediation construction (Thailand and Japan)}

Additionally, a complexity of factors in both macro and meso levels were combined to one latent variable; it could simply explain and interpret as the one important variable function of macro and meso levels. Even if some P values of outer weight (O.W.) were not significant, but P-Values of outer loading (O.L.) were significant (Hair et al.,1995). It meant acceptable to use as the indicator and construct to a higher order of TMAC and JMAC (macro indicator).

Mediation construction consisted of TC1-8(Thailand)/JC1-8(Japan), which showed VIF score was acceptable, and P-values of outer loading were acceptable as well. As a result, mediation factors of country and human developments were accepted to use in this model. 
Table 2.

\begin{tabular}{|c|c|c|c|c|c|c|}
\hline \multicolumn{2}{|l|}{ Thailand MACRO } & \multicolumn{5}{|c|}{ Outer weight(1.0W.) / Outer loading(2.0L.) } \\
\hline Higher construct & Items & Scale & (1.0W.) We & (2.OL.) & (1.0W.) P-I & 2.0L.) \\
\hline \multirow{5}{*}{$\begin{array}{l}\text { TMAC } \\
\text { * Redundancy is not } \\
\text { required in constructing } \\
\text { of formative. }\end{array}$} & TP & \multirow[t]{5}{*}{ Formative } & 0.238 & 0.898 & 0.000 & 0.000 \\
\hline & TE & & 0.293 & 0.892 & 0.000 & 0.000 \\
\hline & TW & & 0.103 & 0.811 & $\underline{0.084}$ & 0.000 \\
\hline & TS & & 0.365 & 0.893 & 0.000 & 0.000 \\
\hline & $\mathrm{TH}$ & & 0.141 & 0.810 & 0.002 & 0.000 \\
\hline
\end{tabular}

Table 3.

\begin{tabular}{|c|c|c|c|c|c|c|c|}
\hline \multicolumn{4}{|c|}{$\begin{array}{l}\text { Thailand mediation } \\
\text { (Country and Human developments) }\end{array}$} & \multicolumn{4}{|c|}{ Outer weight(1.0W.) / Outer loading(2.0L.) } \\
\hline Items & Scale & $\begin{array}{c}\text { T- } \\
\text { values }\end{array}$ & VIF & $\begin{array}{l}\text { Weight } \\
\text { OW. }\end{array}$ & $\begin{array}{l}\text { Weight } \\
\text { OL. }\end{array}$ & $\begin{array}{l}\text { P-values } \\
\text { OW. }\end{array}$ & $\begin{array}{l}\text { P-values } \\
\text { OL. }\end{array}$ \\
\hline TC1 & Formative & 5.597 & 3.414 & 0.330 & 0.838 & 0.000 & 0.000 \\
\hline TC2 & & 4.665 & 5.727 & 0.376 & 0.926 & 0.000 & 0.000 \\
\hline TC3 & & 0.126 & 5.843 & -0.014 & 0.864 & 0.900 & 0.000 \\
\hline TC4 & & 2.001 & 1.238 & 0.071 & 0.141 & 0.045 & 0.005 \\
\hline TC5 & & 0.201 & 4.424 & 0.014 & 0.801 & 0.841 & 0.000 \\
\hline TC6 & & 1.675 & 7.509 & 0.165 & 0.887 & 0.094 & 0.000 \\
\hline TC7 & & 4.561 & 3.769 & 0.278 & 0.861 & 0.000 & 0.000 \\
\hline TC8 & & 0.499 & 3.336 & -0.027 & 0.733 & 0.618 & 0.000 \\
\hline
\end{tabular}

Table 4.

\begin{tabular}{|c|c|c|c|c|c|c|}
\hline \multicolumn{2}{|l|}{ Japan MACRO } & \multicolumn{5}{|c|}{ Outer weight (OW.) / Outer loading (OL.) } \\
\hline Higher construct & Items & Scale & (OW.) We & ts (OL.) & (OW.) P-V & s (OL.) \\
\hline \multirow{5}{*}{$\begin{array}{l}\text { JMAC } \\
\text { *Redundancy is not } \\
\text { required in constructing } \\
\text { of formative }\end{array}$} & JP & \multirow[t]{5}{*}{ Formative } & 0.563 & 0.966 & 0.000 & 0.000 \\
\hline & JE & & -0.131 & -0.722 & 0.000 & 0.000 \\
\hline & JW & & -0.008 & 0.794 & 0.855 & 0.000 \\
\hline & JS & & 0.273 & 0.923 & 0.000 & 0.000 \\
\hline & $\mathrm{JH}$ & & -0.139 & -0.830 & 0.054 & 0.000 \\
\hline
\end{tabular}

Table 5.

\begin{tabular}{|c|c|c|c|c|c|c|c|}
\hline \multicolumn{4}{|c|}{$\begin{array}{c}\text { Japan mediation } \\
\text { (Country and Human developments) }\end{array}$} & \multicolumn{4}{|c|}{ Outer weight(1.0W.) / Outer loading(2.0L.) } \\
\hline Items & Scale & $\begin{array}{c}\text { T- } \\
\text { values }\end{array}$ & VIF & $\begin{array}{l}\text { Weight } \\
\text { OW. }\end{array}$ & $\begin{array}{l}\text { Weight } \\
\text { OL. }\end{array}$ & $\begin{array}{l}\text { P-values } \\
\text { OW. }\end{array}$ & $\begin{array}{l}\text { P-values } \\
\text { OL. }\end{array}$ \\
\hline JC1 & Formative & 3.956 & $\underline{6.747}$ & 0.233 & 0.799 & 0.000 & 0.000 \\
\hline $\mathrm{JC2}$ & & 1.934 & 5.284 & 0.094 & 0.722 & $\underline{0.053}$ & 0.000 \\
\hline JC3 & & 0.391 & 1.765 & 0.012 & 0.502 & $\underline{0.696}$ & 0.000 \\
\hline JC4 & & 5.417 & 1.146 & 0.121 & 0.255 & 0.000 & 0.000 \\
\hline JC5 & & 7.969 & 2.677 & 0.398 & 0.877 & 0.000 & 0.000 \\
\hline JC6 & & 2.253 & 3.944 & 0.118 & 0.847 & 0.024 & 0.000 \\
\hline JC7 & & 0.957 & 1.666 & 0.025 & 0.545 & 0.339 & 0.000 \\
\hline JC8 & & 7.979 & 2.255 & 0.316 & 0.779 & 0.000 & 0.000 \\
\hline
\end{tabular}

** TC1, JC1 = Good disaster or emergency and risk management

$\mathrm{TC} 2, \mathrm{JC} 2=$ Good transportation and road safety

TC3, JC3 = Well management on pollution in control

TC4, JC4 = Well management on food and hygiene

TC5, JC5 = Good health care service system

TC6, JC6 = Well management on elderly and disability care

TC7, JC7 = Crime control and safety

TC8, JC8 = Drugs control and safety 
Thailand Hypothesis Testing: Bootstrapping Direct and Indirect Effect Results

One race scenario (THAILAND)

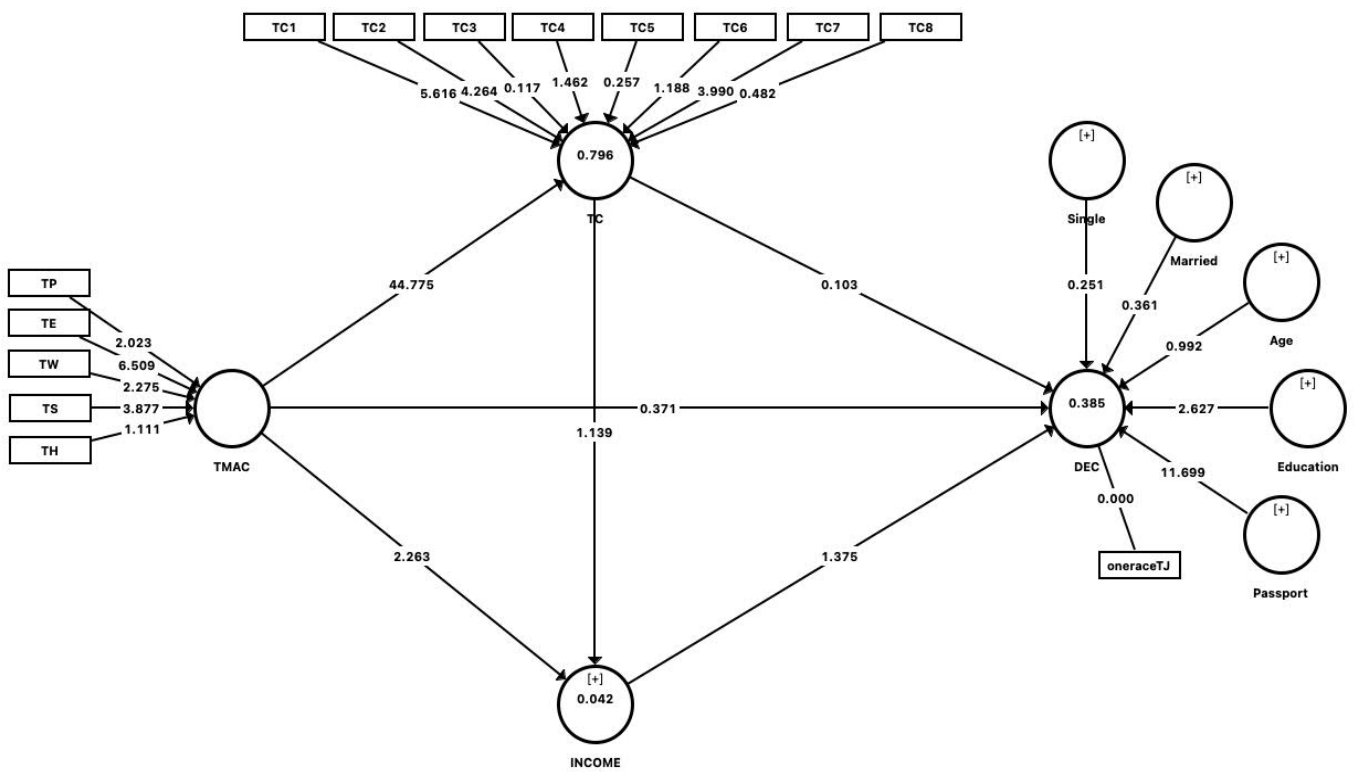

\begin{tabular}{|c|c|c|c|c|c|c|c|c|}
\hline \multicolumn{2}{|r|}{ Hypothesis Relationship } & \multirow{2}{*}{\begin{tabular}{r|} 
StdBeta \\
0.892
\end{tabular}} & \multirow{2}{*}{$\begin{array}{r}\text { StdError } \\
0.020\end{array}$} & T-value & \multirow{2}{*}{\begin{tabular}{|l} 
Decision \\
supported
\end{tabular}} & \multirow{2}{*}{\begin{tabular}{|c|}
$95 \% \mathrm{Cl}$ LL \\
0.857
\end{tabular}} & \multirow{2}{*}{$\begin{array}{r}95 \% \mathrm{Cl} \cup \mathrm{L} \\
0.921\end{array}$} & \multirow{2}{*}{$\frac{p \text {-values }}{0.000}$} \\
\hline $\mathrm{H} 1 \mathrm{a}$ & TMAC $->$ TC & & & 44.775 & & & & \\
\hline $\mathrm{H} 1 \mathrm{~b}$ & TMAC -> DEC & -0.045 & 0.095 & 0.371 & no supported & -0.205 & 0.101 & 0.711 \\
\hline $\mathrm{H} 1 \mathrm{c}$ & TMAC -> Income & 0.352 & 0.160 & 2.263 & supported & 0.095 & 0.626 & 0.024 \\
\hline $\mathrm{H} 2 \mathrm{a}$ & TC -> Income & -0.186 & -0.186 & 1.139 & no supported & -0.487 & 0.091 & 0.255 \\
\hline $\mathrm{H} 2 \mathrm{~b}$ & TC $->$ DEC & 0.018 & 0.104 & 0.103 & no supported & -0.143 & 0.194 & 0.918 \\
\hline H3 & Income $->$ DEC & 0.074 & 0.052 & 1.375 & no supported & -0.012 & 0.161 & 0.169 \\
\hline $\mathrm{H} 4$ & Single $->$ DEC & -0.013 & 0.048 & 0.251 & no supported & -0.093 & 0.065 & 0.802 \\
\hline H5 & Married $->$ DEC & 0.017 & 0.047 & 0.361 & no supported & -0.061 & 0.093 & 0.718 \\
\hline H6 & Age -> DEC & 0.047 & 0.049 & 0.992 & no supported & -0.033 & 0.128 & 0.321 \\
\hline $\mathrm{H} 7$ & Education -> DEC & -0.123 & 0.047 & 2.627 & supported & -0.202 & -0.046 & 0.009 \\
\hline $\mathrm{H} 8$ & Passport -> DEC & -0.601 & 0.052 & 11.699 & supported & -0.684 & -0.513 & 0.000 \\
\hline H9 & TMAC $->$ TC $->$ DEC & 0.017 & 0.093 & 0.102 & no supported & -0.127 & 0.175 & 0.919 \\
\hline $\mathrm{H} 10$ & TMAC $\rightarrow$ TC $\rightarrow$ Income $->$ DEC & -0.013 & 0.017 & 0.740 & no supported & -0.047 & 0.007 & 0.459 \\
\hline $\mathrm{H} 11$ & TMAC -> TC -> Income & -0.168 & 0.159 & 1.124 & no supported & -0.442 & 0.080 & 0.261 \\
\hline $\mathrm{H} 12$ & TMAC $->$ Income $->$ DEC & 0.027 & 0.024 & 1.076 & no supported & -0.004 & 0.072 & 0.282 \\
\hline $\mathrm{H} 13$ & TC $->$ Income $->$ DEC & -0.014 & 0.019 & 0.750 & no supported & -0.052 & 0.008 & 0.453 \\
\hline
\end{tabular}

Dual race scenario (THAILAND)

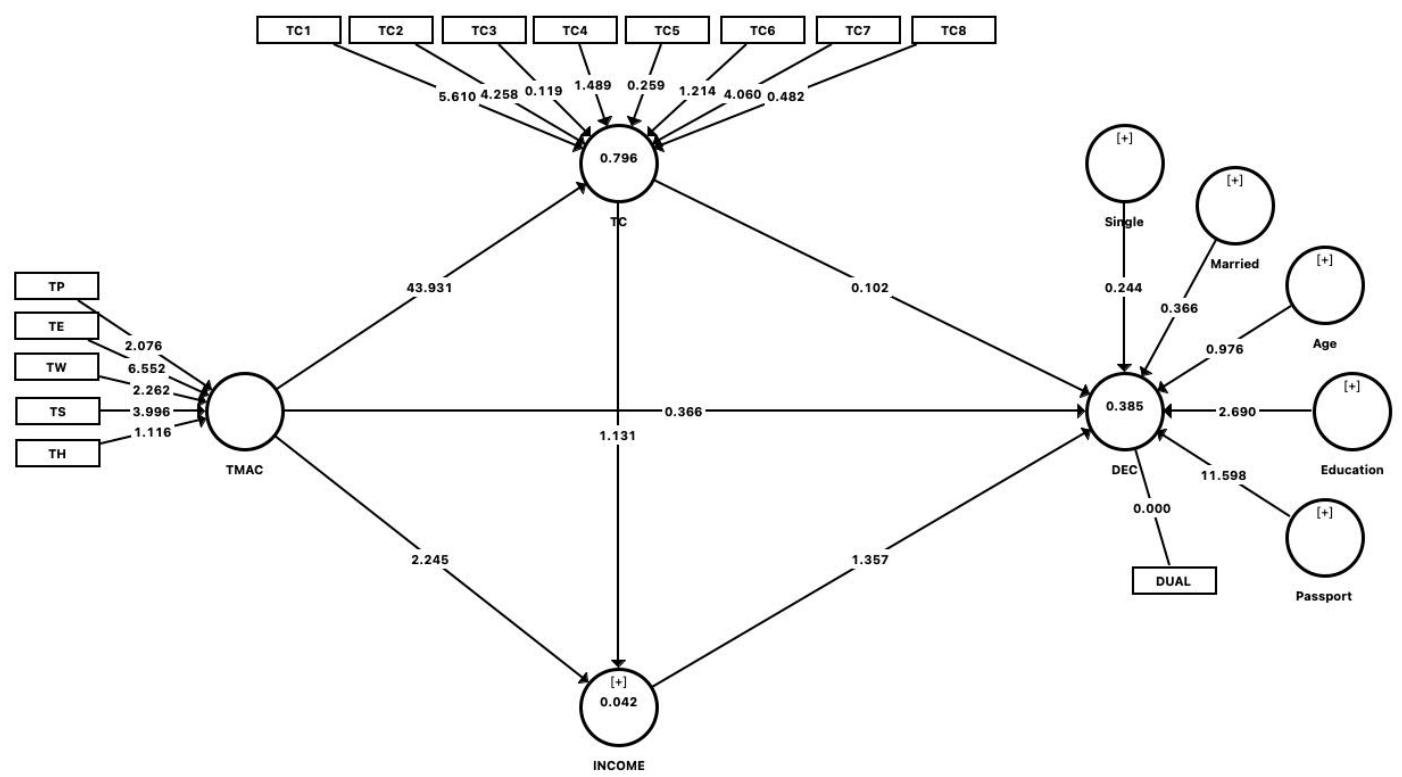




\begin{tabular}{|c|c|c|c|c|c|c|c|c|}
\hline & pothesis Relationship & StdBeta & StdError & T-value & Decision & $95 \% \mathrm{Cl}$ LL & $95 \% \mathrm{Cl}$ UL & $p$-values \\
\hline $\mathrm{H} 1 \mathrm{a}$ & TMAC $->$ TC & 0.893 & 0.020 & 43.931 & supported & 0.857 & 0.922 & 0.000 \\
\hline $\mathrm{H} 1 \mathrm{~b}$ & TMAC -> DEC & 0.045 & 0.097 & 0.366 & no supported & -0.109 & 0.210 & 0.715 \\
\hline $\mathrm{H} 1 \mathrm{c}$ & TMAC $->$ Income & 0.355 & 0.161 & 2.245 & supported & 0.102 & 0.630 & 0.025 \\
\hline $\mathrm{H} 2 \mathrm{a}$ & TC -> Income & -0.190 & 0.177 & 1.131 & no supported & -0.498 & 0.087 & 0.258 \\
\hline $\mathrm{H} 2 \mathrm{~b}$ & TC $->$ DEC & -0.017 & 0.105 & 0.102 & no supported & -0.197 & 0.149 & 0.919 \\
\hline $\mathrm{H} 3$ & Income -> DEC & -0.074 & 0.053 & 1.357 & no supported & -0.162 & 0.012 & 0.175 \\
\hline $\mathrm{H} 4$ & Single -> DEC & 0.014 & 0.050 & 0.244 & no supported & -0.067 & 0.097 & 0.807 \\
\hline $\mathrm{H} 5$ & Married $->$ DEC & -0.015 & 0.046 & 0.366 & no supported & -0.091 & 0.062 & 0.714 \\
\hline $\mathrm{H} 6$ & Age $->$ DEC & -0.048 & 0.049 & 0.976 & no supported & -0.128 & 0.033 & 0.329 \\
\hline $\mathrm{H} 7$ & Education -> DEC & 0.124 & 0.046 & 2.690 & supported & 0.050 & 0.200 & 0.007 \\
\hline $\mathrm{H} 8$ & Passport -> DEC & 0.600 & 0.052 & 11.598 & supported & 0.511 & 0.684 & 0.000 \\
\hline $\mathrm{H} 9$ & TMAC $->$ TC $->$ DEC & -0.016 & 0.094 & 0.101 & no supported & -0.178 & 0.132 & 0.920 \\
\hline $\mathrm{H} 10$ & TMAC $->$ TC $\rightarrow$ Income $->$ DEC & 0.013 & 0.018 & 0.702 & no supported & -0.007 & 0.049 & 0.483 \\
\hline $\mathrm{H} 11$ & TMAC $->$ TC $->$ Income & -0.171 & 0.160 & 1.114 & no supported & -0.453 & 0.077 & 0.265 \\
\hline $\mathrm{H} 12$ & TMAC $->$ Income $->$ DEC & -0.027 & 0.025 & 1.029 & no supported & -0.075 & 0.003 & 0.303 \\
\hline $\mathrm{H} 13$ & TC -> Income $->$ DEC & 0.015 & 0.020 & 0.713 & no supported & -0.007 & 0.054 & 0.476 \\
\hline
\end{tabular}

\section{Japan Hypothesis Testing: Bootstrapping Direct and Indirect Effect Results}

One race scenario (JAPAN)

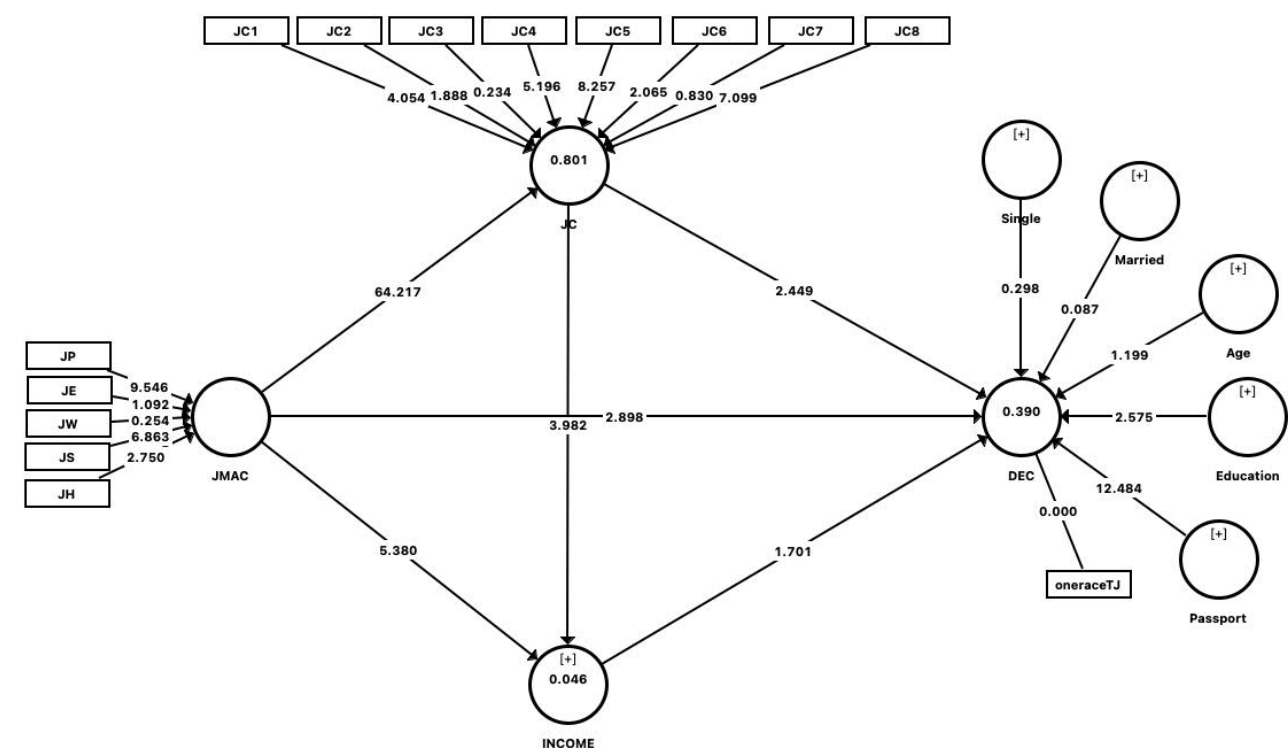

\begin{tabular}{|c|c|c|c|c|c|c|c|c|}
\hline & pothesis Relationship & StdBeta & StdError & T-value & Decision & 95\%CI LL & $95 \% \mathrm{Cl}$ UL & $p$-values \\
\hline $\mathrm{H} 1 \mathrm{a}$ & JMAC $\rightarrow$ JC & -0.897 & 0.014 & 64.217 & supported & -0.918 & -0.872 & 0.000 \\
\hline $\mathrm{H} 1 \mathrm{~b}$ & JMAC -> DEC & 0.282 & 0.095 & 2.898 & supported & 0.131 & 0.441 & 0.004 \\
\hline $\mathrm{H} 1 \mathrm{c}$ & JMAC -> Income & -0.464 & 0.086 & 5.380 & supported & -0.605 & -0.323 & 0.000 \\
\hline $\mathrm{H} 2 \mathrm{a}$ & JC -> Income & -0.353 & 0.088 & 3.982 & supported & -0.499 & -0.210 & 0.000 \\
\hline $\mathrm{H} 2 \mathrm{~b}$ & $J C \rightarrow D E C$ & 0.251 & 0.099 & 2.449 & supported & 0.091 & 0.417 & 0.014 \\
\hline $\mathrm{H} 3$ & Income -> DEC & 0.072 & 0.043 & 1.701 & supported & 0.000 & 0.141 & 0.089 \\
\hline $\mathrm{H} 4$ & Single $->$ DEC & -0.013 & 0.039 & 0.298 & no supported & -0.077 & 0.052 & 0.766 \\
\hline $\mathrm{H} 5$ & Married $->$ DEC & -0.004 & 0.038 & 0.087 & no supported & -0.067 & 0.057 & 0.931 \\
\hline $\mathrm{H} 6$ & Age $->$ DEC & 0.046 & 0.039 & 1.199 & no supported & -0.016 & 0.112 & 0.231 \\
\hline $\mathrm{H} 7$ & Education -> DEC & -0.104 & 0.041 & 2.575 & supported & -0.171 & -0.037 & 0.010 \\
\hline $\mathrm{H} 8$ & Passport -> DEC & -0.575 & 0.046 & 12.484 & supported & -0.651 & -0.498 & 0.000 \\
\hline H9 & JMAC $->$ JC $->$ DEC & -0.226 & 0.090 & 2.413 & supported & -0.377 & -0.082 & 0.016 \\
\hline $\mathrm{H} 10$ & JMAC $->$ JC $->$ Income $\rightarrow$ DEC & 0.022 & 0.014 & 1.586 & no supported & 0.000 & 0.047 & 0.113 \\
\hline $\mathrm{H} 11$ & JMAC -> JC -> Income & 0.317 & 0.081 & 3.893 & supported & 0.185 & 0.450 & 0.000 \\
\hline $\mathrm{H} 12$ & JMAC $\rightarrow$ Income $\rightarrow$ DEC & -0.033 & 0.020 & 1.656 & supported & -0.067 & 0.000 & 0.098 \\
\hline $\mathrm{H} 13$ & JC -> Income -> DEC & -0.025 & 0.016 & 1.597 & no supported & -0.052 & 0.000 & 0.110 \\
\hline
\end{tabular}

Dual race scenario (JAPAN) 


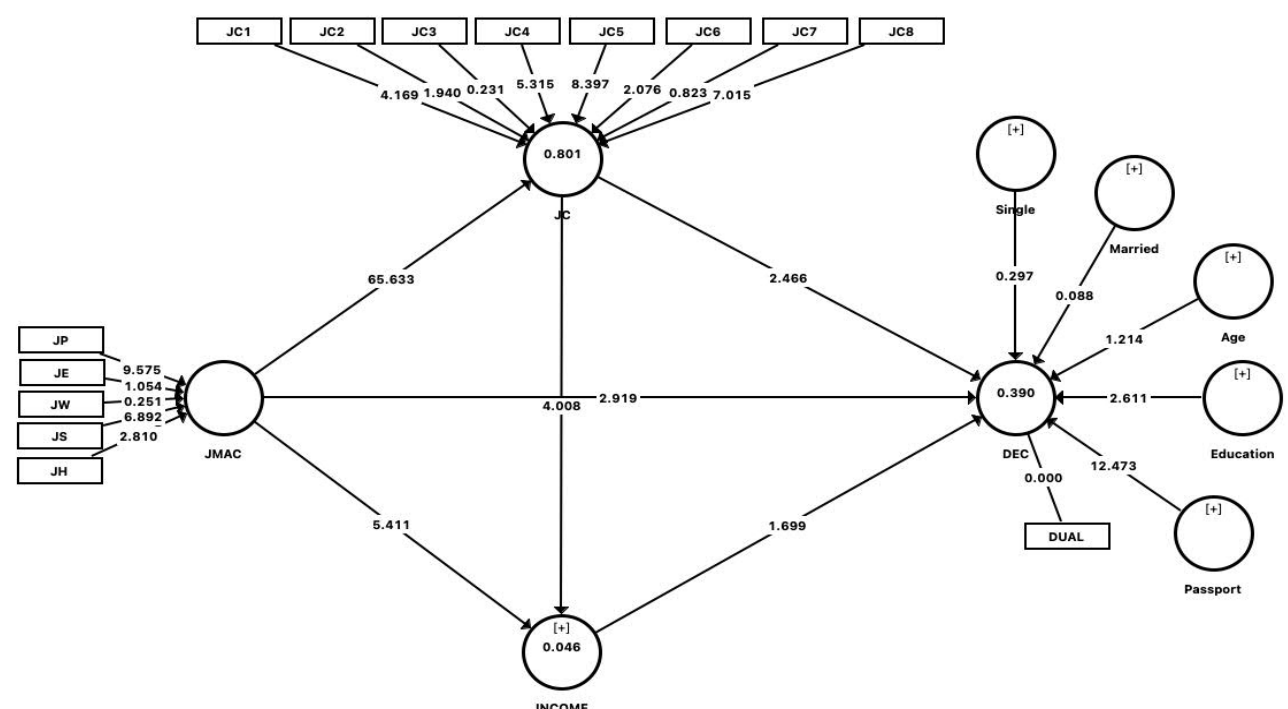

\begin{tabular}{|c|c|c|c|c|c|c|c|c|}
\hline & pothesis Relationship & StdBeta & StdError & T-value & Decision & $95 \% \mathrm{Cl}$ LL & $95 \% \mathrm{Cl}$ UL & $p$-values \\
\hline $\mathrm{H} 1 \mathrm{a}$ & JMAC -> JC & -0.897 & 0.014 & 65.633 & supported & -0.918 & -0.873 & 0.000 \\
\hline $\mathrm{H} 1 \mathrm{~b}$ & JMAC $\rightarrow$ DEC & -0.280 & 0.094 & 2.919 & supported & -0.436 & -0.130 & 0.004 \\
\hline $\mathrm{H} 1 \mathrm{c}$ & JMAC -> Income & -0.464 & 0.085 & 5.411 & supported & -0.604 & -0.324 & 0.000 \\
\hline $\mathrm{H} 2 \mathrm{a}$ & JC -> Income & -0.352 & 0.088 & 4.008 & supported & -0.496 & -0.209 & 0.000 \\
\hline $\mathrm{H} 2 \mathrm{~b}$ & $J C->D E C$ & -0.249 & 0.098 & 2.466 & supported & -0.413 & -0.092 & 0.014 \\
\hline H3 & Income -> DEC & -0.072 & 0.043 & 1.699 & supported & -0.144 & -0.003 & 0.089 \\
\hline $\mathrm{H} 4$ & Single -> DEC & 0.013 & 0.040 & 0.297 & no supported & -0.052 & 0.079 & 0.767 \\
\hline H5 & Married -> DEC & 0.004 & 0.037 & 0.088 & no supported & -0.056 & 0.066 & 0.930 \\
\hline H6 & Age $\rightarrow$ DEC & -0.047 & 0.039 & 1.214 & no supported & -0.111 & 0.016 & 0.225 \\
\hline $\mathrm{H7}$ & Education $->$ DEC & 0.104 & 0.040 & 2.611 & supported & 0.039 & 0.171 & 0.009 \\
\hline $\mathrm{H} 8$ & Passport -> DEC & 0.574 & 0.046 & 12.473 & supported & 0.497 & 0.648 & 0.000 \\
\hline H9 & JMAC -> JC -> DEC & 0.224 & 0.089 & 2.428 & supported & 0.081 & 0.373 & 0.015 \\
\hline $\mathrm{H} 10$ & JMAC $\rightarrow$ JC $\rightarrow$ Income $\rightarrow$ DEC & -0.022 & 0.014 & 1.600 & no supported & -0.047 & -0.001 & 0.110 \\
\hline H11 & JMAC -> JC -> Income & 0.316 & 0.080 & 3.916 & supported & 0.186 & 0.448 & 0.000 \\
\hline $\mathrm{H} 12$ & JMAC -> Income $->$ DEC & 0.033 & 0.020 & 1.658 & supported & 0.001 & 0.067 & 0.097 \\
\hline $\mathrm{H} 13$ & JC $\rightarrow$ Income $\rightarrow$ DEC & 0.025 & 0.016 & 1.609 & no supported & 0.001 & 0.052 & 0.108 \\
\hline
\end{tabular}

According to the aforementioned above, there were 4 scenarios from 2 countries' contexts of a developed and developing country. Meanwhile, the result indicated that two groups of one race and dual race hypothesises presented the same in each country, but different in comparison between two countries context significantly.

Descriptive statistics showed the capabilities and potential of Thai-Japanese multiracial. Over 80\% graduated in higher education level and be able to speak trilingual languages in English, Thai, and Japanese. Moreover, over 70\% was skilled professional worker. As a result, this group could explain to a possibility of choosing place and nationality, and high potential to migrate in both countries equally.

Decision-making choices were divided into two choices of one race and dual race. The process of analysis ran by dichotomous latent, which accumulated to 0 and 1. Moreover, using SMART-PLS runs on a DEC (decision making) prediction from bootstrapping PLS-algorithm for 4 rounds in each scenario.

Particularly, H1a to $\mathrm{H} 3$ as a direct effect, it indicated to macro and meso level which totally different between two countries. Meanwhile, Thailand significantly supported only TMAC to TC and TMAC to INCOME which did not impact DEC (decision making); Japan had all significant support and tended to be significant for DEC (decision making).

From H9-H13 as an indirect effect, Thailand had none of the supported hypothesis while Japan had H9, H11, and H12 which indirect effect to all from JMAC to DEC (decision making).

Micro-level from $\mathrm{H} 4$ to H8 proved in the same way of Thailand and Japan for both groups, which affect to education and passport competency to DEC (decision making). 
As a result of Thailand factors, the reaction of push factors tended to come from country structures and issues of development which impacted the uneffective of escalating the basic income standard, while the descriptive statistic showed the higher potential income of the Thai-Japanese group to make more profit over the standard in Thailand situation. Moreover, the developing status country could explain the need for macro-level development to a better living, and good quality of life, skilled labor or business start-up from other countries played a big role to this situation. Definitely, the macro-level could play a significant role to meso level and income while none impacted nationality decision making. To be able to achieve the status of middle to higher-income country status, Thailand needed to be concerned more in this matter because it possibly foresaw that the policies relate to macro and meso level and it needed to be reconsidered in order to international transformation society and a good management of other nationalities situation systematically. At the same time, the life experiences opportunity and higher income were related to a pull factor which supported a better living potential in this group while they have been living in Thailand. Noticeably, it could possibly address that social-class, and public service access issues play an important matter in macro and meso factors which was significant to nationality decision making as well.

Considering Japan macro and meso factors indicated significant points of nationality decision making. Presently, Japan has become the high-income status along with OECD reported, the ability of policies in macro and meso level impact to income and quality of life until nationality decision making more than Thailand. Furthermore, pull factors of macro and meso level positively impacted to country developments and a well balancing of the social-class population as well which meant Thai-Japanese could live in Japan as same as Japanese people equally.

At this point, it possibly explained that a better life in Thailand is coming from a privileges condition as a Thai-Japanese in a middle or high social class if compared to a middle class or lower class in Japan because of the competitiveness among nationalities which came from the international policies outcome of macro and meso level.

\section{CONCLUSION AND FURTHER RESEARCH}

In the situation of migration management and current issues of push and pull factors around the world, multi-nationality is still underneath as the second generation. There have been a lot of problems in developed countries over a decade in the case of black and white or white and Asian situations. Most of the issues are engraved into governance until social units which categorized into macro meso and micro levels in this study. Solving the problems of multi-nationality conflicts or individual rights need to explore the factors and or concerns in every level relationship, which could or might become a way to measure the actual situation and find a solution to cope with this matter at the present and future generation as well.

\section{To study the possibility factors of multiracial decision making}

Meanwhile, push factors could reference macro and mesostructure problems in the context of a developing country. Precisely, pull factors will gain more credibility of government approach to structural development which will encourage to micro factors level in a positive output and nationality as well.

The concerned factors problem of macro-level in this research indicate that Thailand has a situation concern on "Political and governance", and "Hospital and wellness" respectively meanwhile Japan have a low score on "Economic", and "Working environment". For meso level, Thailand should concern more on "Well management on food and hygiene", "Well management on elderly and disability care", "Drugs control and safety", "Good health care service system", "Well management on pollution in control" respectively, likewise Japan should concern more on "crime control and safety", and "well management on pollution in control respectively". For micro-level as an individual experience, Thailand and Japan have the same result on "Education" and "Passport competency" could support to nationality decision making.

\section{To adjust the factors, impact on multiracial decision making into a model prediction}

The level of analysis could be separated into three layers to understand nationality decision-making under governance and country management issues.

Macro-level has a main factor of political and governance, economic, working environment, society and culture, and hospital and wellness. While the model structure needs to be in the form of macro meso and micro level, this research result manages in the same way and adds meso factors into development issues factor and income range. Additionally, the reference model from migrant decision-making has been 
adapted to use in multi-nationality decision-making. The choices of a migrant to stay or to migrate have been interpreted to one race or dual race.

Country development structure as a meso transition could play a part between macro and micro. In regard, the policy of macrostructure should combine with a good strategy to escalate the structure of the country and human development, then micro-structure will make a significant decision making in the process. This achievement could explain the high development of becoming as a country status and tends to affect on nationality decision making.

\section{To assess a model in the separation of developing and developed country context toward} multiracial decision making

Thailand's macro and meso levels could not support along the way to meso as a positive decision making which will be caused to push factors more than pull factors. While macro factors could not achieve in decision making directly because developing country situation as a meso has been a problem, it will cause to the achievement of government approach and capability to drive the policy strategies in the long-term management of incoming future population nationality issues. Even if Thailand has a benefit of dual nationality (in condition country status), the macro and meso levels seem to be less potential of persuasion to nationality decision making in both one race and dual race, which will be a cause of future population and long-term international labor management.

Japan has more potential to overcome from macro meso to micro better than Thailand especially macro can reach to a director of decision making, and the structure of meso level can achieve to decision making on multiracial nationality as well. As a result, pull factors tend to be boosted from the whole system of macro meso and micro, in the past years that Japan promoted to invite international labors so the proportion of the population could predict to more diversity and international society. According to the Japan nationality act problem, this research suggests that the government should reconsider only one race in Japan to dual race registration legally instead.

\section{Further research direction and limitation}

The results above extend the migration decision-making model built by Castelli, F. (2018) to a possibility to use in multinationality field. This research is exploratory in factors along with structure levels that possibly impact the multinational group; therefore, this model is not enough to conclude the definite pattern and actual answer of nationality decision making. To define more in this model and fulfill the definition of multinationality needs to test with various countries and other multiracial groups in comparison. After that, the pattern of multi nationality decision-making could be a future role model of dual nationality policies.

Moreover, model limitations in this research could not cope with multiple group analyses. To separate the analysis is important according to transfer the answer (aware with no bias) of the possibility nationality decision making into a dichotomous latent variable and running the algorithm in each time. Four scenarios of nationality decision-making could possibly cover the situations of the factor under the context of macro, meso, and micro levels.

The way of interpretation in qualitative is necessary to study more in this situation. The qualitative data will give an advantage to a better understanding in-depth of the factors or variables which indicates to problems and be able to weight the problem and solutions in-country situation along with their nationality status.

Lastly, the multinational group as a second-generation who came from a migrant or long-stay citizenship and its attributes deserve to be updated parallel with the actual possibility situations since the diversity and migrants' movement of global dramatically increases the potential to be able to stay or having interact between two or more countries in the world. It needs to be addressed to well governance management, the policy of country structure, and the changing of social characteristic awareness.

\section{REFERENCES}

Anwar,R. 2019. Expanding skilled-worker mobility: comparing the migration of Indonesian care workers to Taipei, China and Indonesian nurses and careworkers to Japan. edited by Elisabetta Gentile. UK:Edward Elgar Publishing Limited : 209-240. [online]. Available: https://www.adb.org/sites/default/files/publication/517601/skilled-labor-mobilitymigration-asean.pdf 
Bhorat,H. , Meyer,J. \& Mlastsheni. 2002, Skilled Labour Migration from Developing Countries: Study on South and Southern Africa, International migration programme : International labour office (ILO). Geneva. [online]. Available: https://www.ilo.org/wcmsp5/groups/public/---ed_protect/--protrav/---migrant/documents/publication/wcms_201781.pdf

BOI(Thailand Board of Investment). (2019). Annual report 2018. [online]. Available: https://www.boi.go.th/upload/report/2561/index.html

Castelli,F. 2018. Drivers of migration : why do people move?. Journal of Travel Medicine. 25(1). [online]. Available: https://doi.org/10.1093/jtm/tay040

Cheon, Y. , Ip, P. , Haskin, M. \& Yip, T. 2020. Profiles of Adolescent Identity at the Intersection of Ethnic/Racial Identity, American Identity, and Subjective Social Status. Front. Psychol. [online]. Available: https://doi.org/10.3389/fpsyg.2020.00959

Gursharan, S. 2010. Push and pull factors of migration, A case study of brick kiln migrant workers in Punjab, Guru Arjan Dev Institue of Development Studies: India. [online]. Available: https://mpra.ub.unimuenchen.de/30036/1/MPRA_paper_30036.pdf

Hair, J. F. Jr., Anderson, R. E., Tatham, R. L. \& Black, W. C. 1995. Multivariate Data Analysis (3rd ed). New York: Macmillan.

IOM. 2016. Measuring well-governed migration: The 2016 Migration Governance Index. [online]. Available: https://publications.iom.int/system/files/pdf/migration_governance_index_2016.pdf

LaBarrie,T. 2017. Multiracial identity development: illuminating influential factors. Clinical science insights. October,1-8.

Lee, E. 1996. A theory of migration. Demography. 3:47-57.

O'brien,R. 2007. A caution regarding rules of thumb for variance inflation factors. Qual Quant 41. 673-690. [online]. Available: https://doi.org/10.1007/s11135-006-9018-6

OECD. 2017. OECD Economic surveys: Japan. [online]. Available: https://www.oecd.org/economy/surveys/Japan-2017-OECD-economic-survey-overview.pdf

OECD. 2019. Multi-dimensional Review of Thailand(Volume 2):In-depth Analysis and Recommendations. [online]. Available: https://doi.org/10.1787/9789264307674-en

Parker, K. et al. 2015. Multiracial in America: Chapter 6: Partisanship, Policy Views and Social Values. Pew Research Center. [online]. Available: https://www.pewresearch.org/socialtrends/2015/06/11/chapter-6-partisanship-policy-views-and-social-values/

Perlman,J and Waters,Mc. (2002). The new race question: How the census counts multiracial individuals. New York: Russell Sage Foundation.

Radina,E. \& Cooney,T. 2000. Relationship Quality between Multiracial Adolescents and Their Biological Parents. American Journal of Orthospychiatry. 70(4):45-54. DOI:10.1037/h0087763

Siripen,Y. \& Wongleedee, K. 2014. International tourists' travel motivation by push-pull factors and decision making for selecting Thailand as destination choice. International Journal of Social, Behavioral, Education, Business and Industrial Engineering, 8(5): 1348-1353.

Said,J. \& Maryono,M. 2018. Motivation and Perception of Tourists as Push and Pull Factors to Visit National Park. ICENIS 2017, Web of Conferences 31, 08022. [online]. Available: https://www.e3sconferences.org/articles/e3sconf/pdf/2018/06/e3sconf_icenis2018_08022.pdf

Vespa,J. , Medina,L. , Armstrong,D. 2020. Demographic Turning Points for The United States: Population Projections for 2020 to 2060. US. GOVERNMENT CENSUS. [online]. Available: https://www.census.gov/content/dam/Census/library/publications/2020/demo/p251144.pdf 